\title{
A new species of the jumping spider genus Pblegra Simon, 1876 from India (Aranei: Salticidae: Aelurillina)
}

\author{
Новый вид пауков-скакунчиков из рода Pblegra Simon, 1876 \\ из Индии (Aranei: Salticidae: Aelurillina)
}

\author{
Dhruv A. Prajapati \\ Ахрув А. Праджапати
}

Research and Development Centre, Bharathiar University, Coimbatore - 641 014, India.

GEER Foundation, Indroda Nature Park, Gandhinagar, Gujarat 382007, India.

E-mail: dhruvspidy215@gmail.com

KEY WORDS: Araneae, distribution, South Asia, taxonomy.

КЛЮЧЕВЫЕ СЛОВА: Araneae, распространение, Южная Азия, таксономия.

ABSTRACT. A new species of jumping spiders from the genus Phlegra Simon, 1876 is described from India. A detailed morphological description, diagnosis and illustrations of the copulatory organs are provided. Distribution of the new species is mapped.

How to cite this article: Prajapati D.A. 2019. A new species of the jumping spider genus Phlegra Simon, 1876 from India (Aranei: Salticidae: Aelurillina) // Arthropoda Selecta. Vol.28. No.4. P.575-578. doi: 10.15298/arthsel. 28.4.11

РЕЗЮМЕ. Описан новый вид пауков-скакунчиков из рода Phlegra Simon, 1876 из Индии. Приводятся детальное описание, диагноз и иллюстрации копулятивных органов. На карте показано распространение нового вида.

\section{Introduction}

The genus Phlegra is widespread and currently includes 80 valid species [WSC, 2019], of which 37 species (nearly a half) are reported from Asia. Four Phlegra species have been reported/described from India: P. davidi (Caleb, Mungkung et Mathai, 2015), P. dhakuriensis (Tikader, 1974), P. fasciata (Hahn, 1826) and $P$. prasanna Caleb et Mathai, 2015 [WSC, 2019], but the validity and generic assignment of some of these species require further studies. The dark-bodied $P$. prasanna was recently described from South India [Caleb et al., 2015]; in the present paper, a new species of Phlegra from India which has a similar general appearance to $P$. prasanna is diagnosed and described.

\section{Material and methods}

The studied specimens were hand-collected and examined by means of a LEICA S8AP0 stereomicro- scope. All measurements are in $\mathrm{mm}$. The length of palp and leg segments is given as follows: total (femur, patella, tibia, metatarsus (except palp), tarsus). Spine positions are as follows: prolateral, dorsal, retrolateral and ventral. $\mathrm{B} / \mathrm{W}$ drawings were made by means of a drawing apparatus attached to the LEICA microscope. Digital images were taken by a Leica DFC2900 digital camera attached to the Leica M205 A stereomicroscope, with the software package Leica Application Suite (LAS), version 4.5.0. The type series has been deposited in the reference collection of the Gujarat Ecological and Educational Research (GEER) Foundation, Gandhinagar, India.

Abbreviations used in the text are as follows: ALE anterior lateral eye, AME - anterior median eye, PLE posterior lateral eye, PME - posterior median eye, I-IV 1 st to 4 th legs.

\section{Description}

$$
\text { Phlegra Simon, } 1876
$$

Type species: Attus fasciatus Hahn, 1826.

Phlegra abhinandanvarthamani sp.n. Figs 1-9, Map.

TYPES: HоLотуре $O^{7}$ (GJSP874361A) from India, Gujarat, Ahmedabad, Gujarat Universiry $\left(23^{\circ} 02^{\prime} 11.72^{\prime \prime} \mathrm{N}, 72^{\circ} 32^{\prime} 33.40^{\prime \prime} \mathrm{E}\right)$, $53 \mathrm{~m}$ a.s.1., from foliage, 16.11.2015, D.A. Prajapati. - PARATYPE: $1 \mathrm{O}^{7}$ (GJSP874361B), together with the holotype.

ETYMOLOGY. The specific epithet is dedicated to an air warrior of the Indian Air Force, a Wing Commander Abhinandan Varthaman, for his valorous actions and courage during the India-Pakistan standoff in 2019.

DIAGNOSIS. By its general appearance, the new species is similar to $P$. prasanna but can be easily distinguished from it by the bi-ramous, broad and blunt retrolateral tibial apophysis (Figs 6,8) (bi-ramous, but narrow and spiniform in P. prasanna; see figs 54 and 56 in Caleb et al. [2015]); 

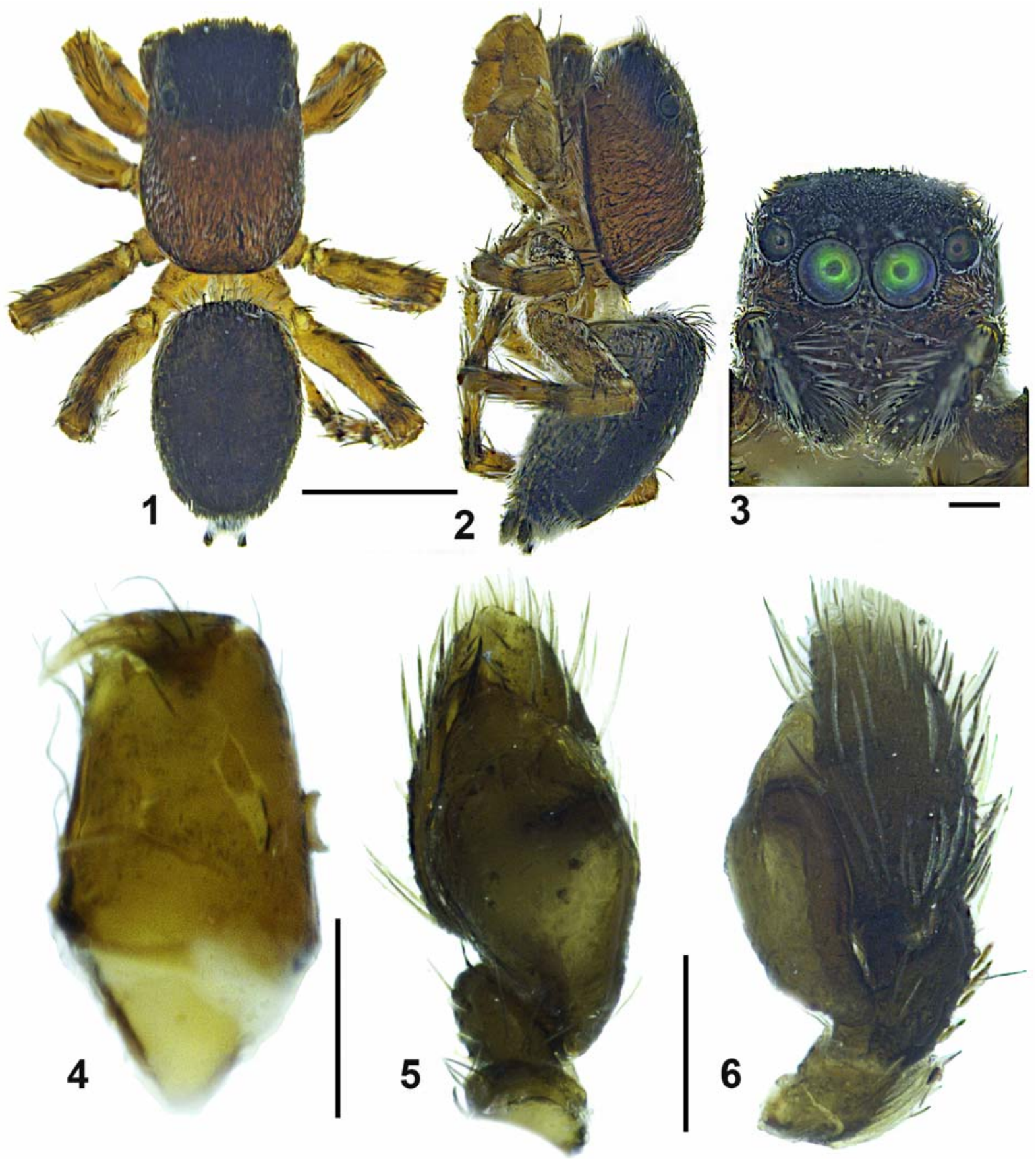

Figs 1-6. Holotype male of Phlegra abhinandanvarthamani sp.n.: 1 - general appearance, dorsal view; 2 - ditto, lateral view; 3 carapace, frontal view; 4 - chelicerae and endites, ventral view; 5 - left palp, ventral view; 6 - ditto, retrolateral view. Scale bars: 1,2 $(1 \mathrm{~mm}) ; 3-6(0.2 \mathrm{~mm})$.

Рис. 1-6. Голотип-самец Phlegra abhinandanvarthamani sp.n.: 1 - общий вид, дорзально; 2 - тоже, сбоку; 3 - головогрудь, спереди; 4 - хелицеры и максиллы, снизу; 5 - левая пальпа, вид снизу; 6 - тоже, вид сбоку-сзади. Масштаб: 1, 2 (1 мм); 3-6 (0,2 мм).

the embolus stout and flattened, with a broad base and narrow tip (Fig. 9) (the comparatively longer, thread-like and slightly bent embolus in P. prasanna; see figs 53 and 55 in Caleb et al. [2015]).

DISTRIBUTION. The type locality only: Ahmedabad, Gujarat, India (Map).
DESCRIPTION. MALE (the holotype, Figs 1-9). Carapace pear-shaped, covered with numerous setae; cephalic region blackish brown, eyes encircled by minute whitish setae, apical margin of anterior eye row with longer setae; thoracic region brownish with a dark brown reticulation (Figs 1-3). Clypeus, chelicerae, endites, labium and sternum 

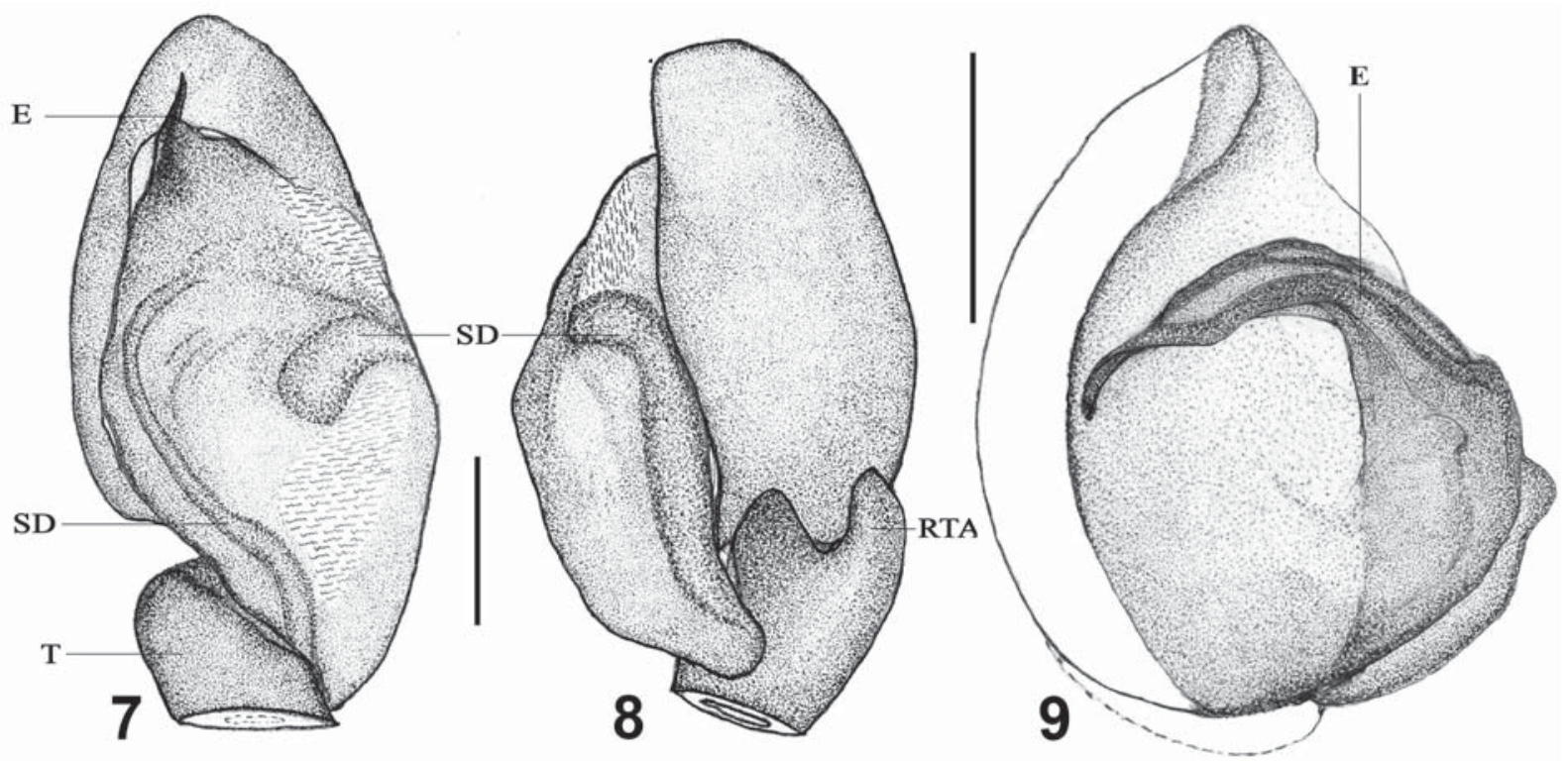

Figs 7-9. Holotype male left palp of Phlegra abhinandanvarthamani sp.n. (holotype $\left.0^{7}\right): 7$ - ventral view; 8 - retrolateral view; $9-$ embolus, apical view. Scale bars: 7, $8(0.1 \mathrm{~mm}), 9(0.05 \mathrm{~mm})$. Abbreviations: E - embolus; RTA — retrolateral tibial apophysis; SD sperm duct; $\mathrm{T}$ - tibia.

Рис. 7-9. Левая пальпа голотипа-самца Phlegra abhinandanvarthamani sp.n. (holotype $0^{7}$ ): 7 — вид снизу; 8 - вид сбоку-сзади; 9 — эмболюс, вид сверху. Масштаб: 7, 8 (0,1 мм), 9 (0,05 мм). Сокращения: Е — эмболюс; RTA — ретролатеральный отросток; $\mathrm{SD}$ - семенной каналец; T - голень.

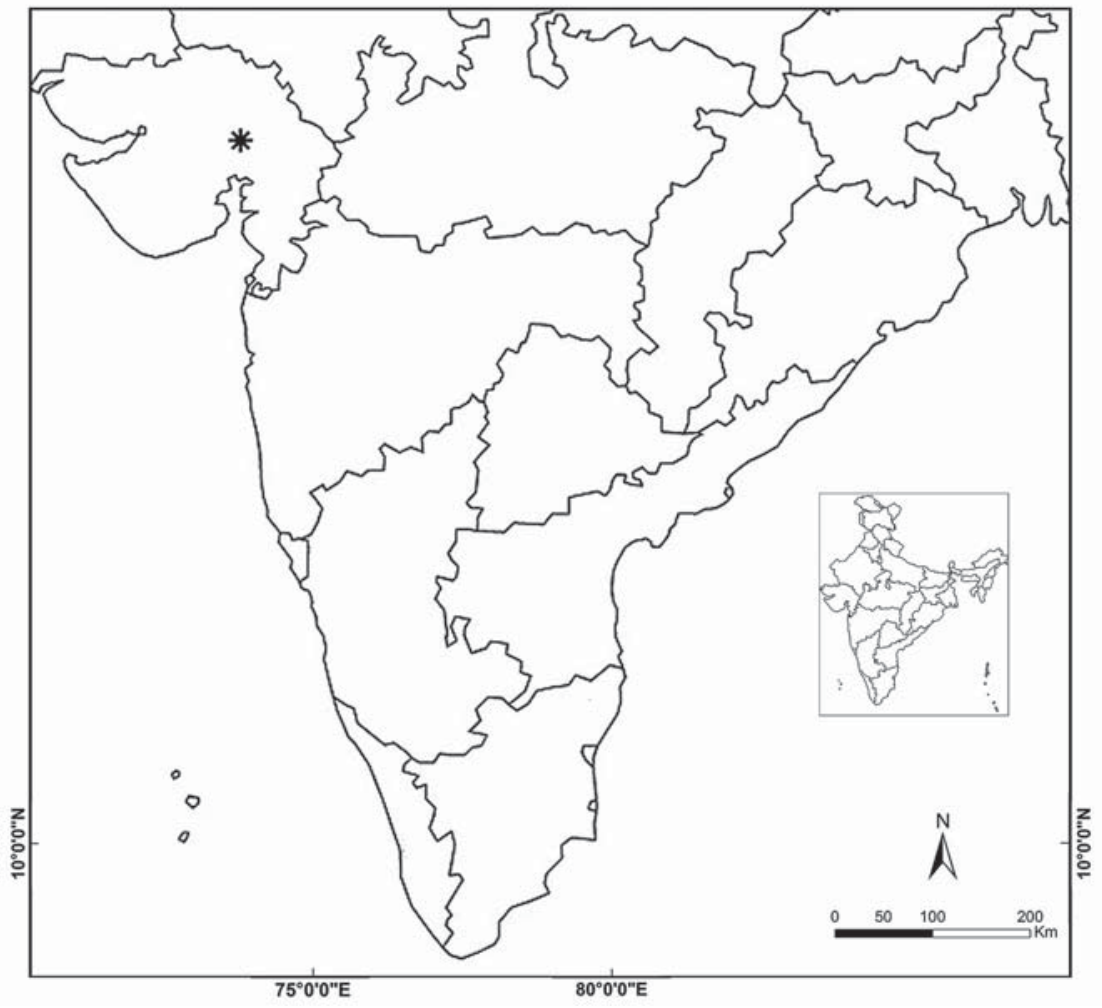

Map. The type locality of Phlegra abhinandanvarthamani sp.n. in India.

Карта. Типовой локалитет Phlegra abhinandanvarthamani sp.n. в Индии. 
brownish. Clypeus with scattered whitish setae. Chelicerae with two promarginal and one retromarginal teeth (Fig. 4); fangs medium sized, yellowish brown (Fig. 4). Legs yellowish brown; first two pairs with black blotches laterally, last two pairs with black bands at each segments along with a longitudinal black band on the dorsal side of femora. Abdomen oval and blackish brown, with transparent and dark brown setae; the posterior tip of abdomen with a bunch of whitish setae (Figs 1-2); lateral sides are covered with whitish setae (Fig. 2); venter whitish, with a discontinuous longitudinal black band. Spinnerets blackish. Body length 2.95 . Carapace length 1.57, width (at the middle) 1.03, height (at the middle) 0.74 . Abdomen length 1.38 , width (at the middle) 0.95 , height (at the middle) 0.85. Eye diameter: ALE 0.13, AME 0.24, PLE 0.16, PME 0.05. Eye interdistances: AME-AME 0.03, AME-ALE 0.03, ALE-ALE 0.63, ALEPME 0.20, PLE-PLE 0.69, PME-PME 0.74, PME-PLE 0.10. Clypeal height at ALE 0.22, at AME 0.07. Cheliceral length 0.30. Measurements of palp and legs: Palp 0.93 [0.33, $0.12,0.13,0.35]$, I $1.81[0.63,0.28,0.39,0.24,0.27]$, II $1.71[0.62,0.28,0.33,0.20,0.28]$, III $1.86[0.64,0.23,0.32$, $0.37,0.30]$, IV $2.92[0.93,0.34,0.64,0.57,0.44]$. Leg formula: 4312. Spination. Palp: 0100, 0000, 0000, 0000; legs: femora I-II 0500, III-IV 0700; patellae I-II 0000, IIIIV 1010; tibiae I 3004, II 1004, III 2032, IV 3133; metatarsi I 1014, II 2014, III 1312, IV 3523; tarsi I-IV 0000. Palp (Figs 5-8): palpal segments dark brown, with a significant amount of white hairs on dorsal side of the cymbium, tibia and patella as in Fig. 3. Embolus stout, flattened with a prominent curve which can be seen from apical view, embolic base broader and narrow tip directed at 12 o'clock position (Figs 5, 7, 9). Sperm duct proximally thick and distally narrow (Figs 5-8). Retrolateral tibial apophysis bi-ramous, broad, blunt and U-shape as seen in retrolateral view (Figs 6, 8).

Female is unknown.

Acknowledgements. I am grateful to Dr P.A. Sebastian of the Sacred Heart College, Thevara, Cochin, for providing me with the research facilities and his great support during this work. I am indebted to Dr Dmitri Logunov (Manchester, UK) for providing me with valuable suggestions and for editing the manuscript. I also wish to thank Dr A.V. Sudhikumar (Christ College, Irinjalakuda, Kerala), Miss Priyal Prajapati and Mr Nitin Patel (GEER Foundation, Gandhinagar) for their generous help at the initial stage of this research.

\section{References}

Caleb J.T.D., Mungkung S., Mathai M.T. 2015. Four new species of jumping spider (Araneae: Salticidae: Aelurillinae) with the description of a new genus from South India// Peckhamia. Vol.124.1. P.1-18.

WSC 2019. World Spider Catalog (version 20.0). Natural History Museum Bern; online at: http://wsc.nmbe.ch (accessed on 30 April 2019). doi: 10.24436/2

Responsible editor D.V. Logunov 